\title{
CSR Implication and Disclosure in Higher Education: Uncovered Points. Results from a Systematic Literature Review and Agenda for Future Research
}

\author{
Mahalaxmi Adhikariparajuli ${ }^{1} * *$ (D) Abeer Hassan $^{2}$ and Benedetta Siboni ${ }^{3}$ (I) \\ 1 School of Economics, Finance and Accounting, Coventry University, Coventry CV1 5FB, UK \\ 2 School of Business and Creative Industries, University of the West of Scotland, Paisley PA1 2BE, UK; \\ abeer.hassan@uws.ac.uk \\ 3 Department of Management, University of Bologna, Forlì Campus, 47121 Forlì, Italy; \\ benedetta.siboni@unibo.it \\ * Correspondence: ad4615@coventry.ac.uk
}

Citation: Adhikariparajuli, M.;

Hassan, A.; Siboni, B. CSR

Implication and Disclosure in Higher

Education: Uncovered Points. Results from a Systematic Literature Review and Agenda for Future Research. Sustainability 2021, 13, 525. https:// doi.org/10.3390/su13020525

Received: 9 December 2020

Accepted: 2 January 2021

Published: 7 January 2021

Publisher's Note: MDPI stays neutral with regard to jurisdictional clai$\mathrm{ms}$ in published maps and institutional affiliations.

Copyright: $\odot 2021$ by the authors. Licensee MDPI, Basel, Switzerland. This article is an open access article distributed under the terms and conditions of the Creative Commons Attribution (CC BY) license (https:// creativecommons.org/licenses/by/ $4.0 /)$.

\begin{abstract}
This research reviews and analyzes prior corporate social responsibility (CSR) studies centered on its implications and disclosure in higher education institutions (HEIs). Nine major databases were analyzed to review research articles from various business, management, higher education, and accounting journals for the period of 2004-2020. We follow the seven-step systematic review guidelines developed by Fink 2019 and we base our review analysis on fifty-eight journal articles. The systematic literature review results show a significant increase in the number of CSR article publications and the extent and trend of disclosure. The majority of prior research was based on questionnaires to evaluate the HEIs curriculum and focus on the CSR implication process. However, HEIs are still lagging behind in CSR implication and disclosure, and with a long way to go to obtain sustainability goals. From the study, several opportunities for future research emerged. This study can be useful for HEIs policymakers and practitioners to access the usefulness of CSR implications and disclosures in HEIs. In addition, this analysis assists scholars to explore in-depth the uncovered points related to CSR in HEIs context. This is the first systematic review of CSR implications and disclosures that comprehensively covers higher education institutions as a sector and presents a reference for academic literature from 2004 to 2020.
\end{abstract}

Keywords: corporate social responsibility (CSR); higher education institutions (HEIs); systematic literature review; sustainability; disclosure

\section{Introduction}

Investors and society demand organizations to be accountable towards stakeholders and be transparent about their social activities [1,2]. As such, from around the 1990s, corporate social responsibility (CSR) reports were published alongside traditional financial statements with the expectation that organizations should be good citizens, fulfil social roles and tackle social problems, thus obtaining social recognition by engaging actively in dialogue with stakeholders [3,4]. In this vein, higher education institutions (HEIs) are responsible for the significant influence over a large population of future leaders $[1,5]$. This influence is not limited to teaching and research, but it extends to include the need and ability to maintain its long-term performance better than its competitors [6]. Therefore, there is a need to recognize CSR as a core component of the function of universities, rather than as a separate consideration [7,8]. To participate in CSR activities, universities started gearing their key performance indicators (KPIs) towards social responsibility by voluntarily integrating social activities into their core policy and social performance measurements $[9,10]$. Research on CSR within public and HEIs sectors has recently received greater academic interest [7,11].

Although many scholars have started to publish academic articles on CSR, the longitudinal study carried out by Ref. [12] on CSR and environmental analysis is still considered a 
pioneer CSR study, with three thousand, seven hundred and forty citations [13]. Recently, in-depth investigations have been carried out from various perspectives in different sectors and geographical regions. Prior reviews were related to accounting [14,15]. Others were related to small and medium-sized enterprises (SMEs) [16,17].

Following this vein, it is vital to mention that other pieces of literature employed the case study approach, such as the CSR implication in HEIs in Turkey by Ref. [3], and the CSR teaching approach and its implementation by graduate employees $[18,19]$. Some of the earlier research of this kind was based in the public sector [20-22].

However, one earlier systematic literature review (SLR) focused on the HEIs sector [23]. This study highlighted strategy, sensing opportunities and threats related to social responsibility, establishing joint decision-making processes and engagement in agile project management, including rapid initiative deployment and the transformation of assets to fulfil social obligations. Nevertheless, relying on strategic management theory, the scholars explicitly exclude the practical implications of CSR and its disclosure that address internal and external audiences. Additionally, another SLR in HEIs has focused on core activities such as teaching and learning, research, social projection and educational institutions' management. The aim was to contribute to the Sustainable Development Goals (SDGs) through wastage management, sustainable campuses, gender equality policies and stakeholder's collaboration, or exploring a change in the graduates' profile, teachers' and students' training, and innovative teaching methodologies were included [24].

As such, the integration of ethics, CSR and sustainability within the HEIs context could play an essential role in addressing the complexity of the social, economic, and environmental context of the society, and help in obtaining the sustainable development goals [25]. Particularly, CSR studies in HEIs have a strong influence on students' values, ethics and learning behaviors, which could effect graduates' work through the conceptual framework and practical tools to enhance CSR $[25,26]$. CSR implication in the HEIs curriculum is the relevant force in shaping students attitudes and perception for sustainable society [27]. So, there is a growing need to strengthen, structure, and synthesize the existing literature on CSR, sustainability and the sustainable development goals [28]. In addition, HEIs should implement stakeholder engagement, and CSR in practice, to achieve the agreed outcomes in sustainability development [29]. Therefore, the current research aims to bridge the gap in CSR literature through the expansion of CSR studies, research synthesis, and the exploration of research efforts and techniques, and provide advice to future researchers. Our SLR is based on HEIs only, allowing for a defined lens to analyze different methodologies, built upon distinct data sources, focusing on various geographic regions and exploring different periods.

The study makes several contributions to the extent of CSR in the HEIs literature. This is the first comprehensive SLR systematic in-depth review of CSR's implication and disclosure in HEIs, achieved by analyzing fifty-eight articles published in scientific journals. In doing so, it explores the gap in earlier CSR literature in the HEIs sector, and recommends an agenda for future research in this dimension. Additionally, this SLR highlights the multiple actors employed in CSR studies, such as students and the CSR curriculum. Second, this systematic review provides a comprehensive content analysis of self-reported limitations and future directions in HEIs, which are not employed by earlier scholars in the HEIs sector. Finally, in carving out the significant issues of CSR's implication in HEIs, our findings indicate where potential interventions could promote the ultimate determinants and consequences of CSR in HEIs. We believe this contributes to the practice of CSR by HEIs.

The paper is structured as follows. The methodology is explained in the next section. Section three provides the findings and their discussion. Section four gives critical analysis and section five explains the conclusions and the plan for future research avenues. 


\section{Methodology}

In light of the increasing CSR research output, and the conflict in its findings, an SLR plays a crucial role in terms of "the nuggets of knowledge which lies underneath", [30] (p. 21), [31] (p. 306). While several systematic reviews exist, a distinction is commonly made on the basis of geographical region, developing and developed countries, public listed companies (PLCs) and SMEs, corporate governance, and value relevance $[14,32,33]$. However, in the HEIs context, in contrast, the SLR approach should be rigorous, replicable in manner, and transparent to reduce the risk of bias [30,34]. In this sense, a systematic review can synthesize the existing body of literature, exploring research patterns, themes and gaps, and identifying the conceptual content of the research field [35,36].

For this SLR, we followed the SLR (a process of seven steps) proposed by Ref. [37]. We concluded that this guideline was suitable for the CSR review as the guidelines are widely employed in prior SLRs in accounting disclosure, carbon accounting [38], sustainability reporting [39], carbon disclosure [40], and integrated reporting [30]. We believe this structure is relevant in the context of HEIs because the SLR should be systematic, explicit in presenting how the review was conducted, comprehensive in its scope to cover relevant materials, and be reproducible by other scholars who could be reviewing a similar topic [36]. By implementing [38] the seven-step approach, this SLR in HEIs ensures a replicable, transparent and scientific way of conducting a review, as suggested by Ref. [39].

\subsection{Step One}

The first step of the SLR is to specify the research question. As well as offering a plethora of contingent advantages, the CSR movement has come to face an increased variety of practical difficulties in HEIs due to a lack of clear guidelines, and this has changed the track of momentum $[5,19,23]$. However, HEIs are engaged in addressing the social phenomenon of educating people, and are a proactive area that can entertain the social responsibility paradigm via a competitive strategy [21,24-26]. Our initial objective was to present a current overview of the state of research on CSR practice in HEIs, to determine the general extent and trends, and to identify significant research gaps and inconsistencies in the results (if any). Thus, we aim to shed light on the potential implications, reporting and disclosure of CSR in HEIs. More notably, we inductively refined our aim to answer the following research question:

What significant CSR implications, as concerns reporting and disclosures, have been identified in prior research related to HEIs?

\subsection{Step Two}

The second step was the identification of the relevant databases. We selected the Social Science Citation Index (SSCI) for a broad coverage of peer-reviewed journals, published in English, covering accounting, management and disclosure in HEIs. In the SSCI, all journals related to social science are captured comprehensively, and this includes the academic outcomes and impact factor [30,40]. This SLR includes data harvested from JSTOR, Sage Publication, Science Direct, Emerald, Springer Link, Wiley Online Library, SCOPUS and Taylor and Francis, a total of nine online databases which are based on earlier relevant SLRs $[30,41-43]$. Furthermore, we employed google scholar to cross-check the research articles; it did not add many articles, though it demonstrated the research validity [44].

\subsection{Step Three}

The third step was the process of choosing search terms. To ensure exhaustive and extensive research, we searched articles with the phrases: "CSR in HEIs", "CSR disclosure in universities", "CSR and HEIs curriculum", "CSR and disclosure and universities", and "CSR in the education sector", to keep the selection terms as board as possible. The key words were previously identified and discussed by all authors. This was to ensure that the search did not miss any relevant articles and adequately covered the research field. We followed the searching guidelines suggested by Refs. [24,45,46]. This involved searching 
the abstracts, titles and keywords in all databases from 2004-2020. However, in this SLR, working papers, book chapters, masters and PhD dissertations were not included, as suggested by Refs. [24,30,47].

\subsection{Step Four}

An SLR might be methodologically considered as content analysis, and can be employed quantitatively by examining descriptive aspects and qualitatively through evaluating content criteria $[39,48]$. Therefore, the fourth step considered the specific practical screening criteria for how we included or excluded articles for SLR. We only considered peer-reviewed journal articles and those in the English language. Our search strategy resulted in a total of one hundred and sixteen articles. Of this sample, sixteen articles were obtained from JSTOR, sixteen articles were from Taylor and Francis, fifteen articles from SSCI, twelve from Science Direct, eight from Sage Journals, ten from Emerald, eight from Springer, twenty-one from SCOPUS and ten from Wiley Online Library, respectively. After duplicate deletion, eighty-one articles remained preliminarily. Subsequently, all contributing authors screened all articles independently, following predetermined steps and criteria.

At the first round of screening, a quick content check was employed for each article, and articles that did not focus on the topic of CSR in HEIs, were not in English and were nonacademic journals were excluded from the review. The second round of screening eliminated all articles lacking clear perspectives on CSR's implications, reporting and disclosures. To evaluate the non-existence of CSR's implications and disclosure perspectives, we searched the title of each article, as well as its abstract and the keywords, for descriptive terms (e.g., CSR embedded in HEIs curriculum, CSR reporting and management quality, graduate's perspective on CSR and CSR disclosure in HEIs) and words associated with the practical implications of the CSR concept (e.g., CSR engagement, CSR strategy, CSR action, CSR learning process, CSR teaching). Finally, we excluded the systematic review from further analysis as this supported our intention to explore the original line aimed at CSR in the existing research. Results from all the authors were compared after each screening process. Any disagreements related to some of the articles were further scrutinized, and a conclusion was reached after a subsequent discussion took place involving all the authors. After this process, fifty-eight articles were deemed to be of central relevance to this SLR (Appendix A).

\subsection{Step Five}

The fifth step was to review the identified literature and synthesize the results. To accomplish this review, all the authors were independently involved with the collected resources. They summarized each article in terms of related information, with CSR implications (in terms of CSR in practice, HEIs' roles in developing the ethical, responsible, sustainable behavior of students through teaching, learning and research can be integrated $[27,28,49]$ ) and CSR disclosure (this is the combination of CSR reporting and publishing accountability as regards the society, economy and environment [24,29]). In order to conclude and synthesize the results, we exclusively focused on a year of CSR research publications, the variables employed in the research, research publications via geographical regions, the names of journals, the research methods, the sample size, critical analysis of the variable measured, the emerging issues in the prior research, and the limitations of an earlier study.

\subsection{Step Six}

The sixth step involved a comparison of the individual summaries created by all the authors. These were subsequently compared, discussed and converted into one original file.

\subsection{Step Seven}

Finally, after the thematic analysis, descriptive categories were employed to provide additional information about the reviewed articles (see Appendix A, Table A1). To explore 
the prior literature, the following descriptive categories were applied: year of publication; variables employed in the research; articles published per geographical region; name of the journal; research method; sample size; and source of data. This SLR culminates with its limitations, conclusions and recommendation for further research. All 58 journal articles are included as final list (see Appendix B).The synthesis of this SLR's descriptive and thematic results is presented in the following sections. Figure 1 presents the PRISMA flowchart of this SLR.

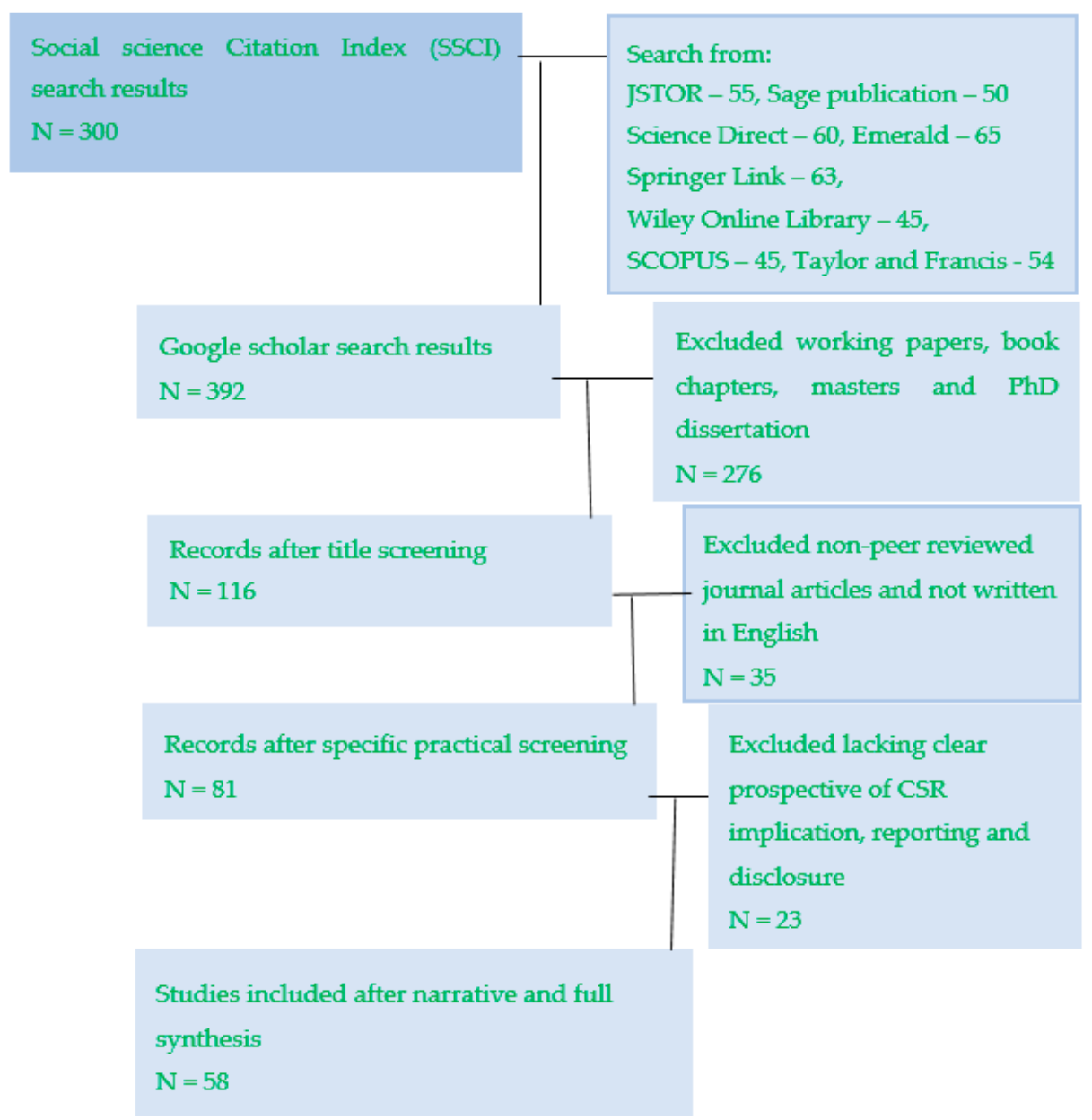

Figure 1. PRISMA flowchart of Systematic Literature Review (SLR)

\section{Descriptive Analysis of CSR Implications, Disclosure and Action}

\subsection{The Extent and Trend of CSR Research}

Figure 2 presents the number of CSR articles in HEIs published by year. The volume fluctuates widely, as explored by Refs. [8,30,50]. In this context, fewer articles were observed in 2004-2006 and 2007-2009. In contrast, 2013-2015 was the most popular period for CSR publication, as around twenty-six percent (fifteen out of fifty-eight) were published during this period. For the year 2020, this review only covered the articles from the databases in the first three months, namely January to March (i.e., three articles); therefore, it is expected that more articles will be published on the topic during this period. The highest number of CSR studies in HEIs was about 2013, and this is consistent with Ref. [51], who found the highest number of sustainability reporting articles published in HEIs in 2013-2014. This might be due to the consequences of the 2008 financial crisis, including higher demands for public accountability, transparency, and performance and risk disclosure [52]. Furthermore, the increasing trend of CSR in HEIs article publication indicates that researchers were curious about the CSR implication in a HEIs context, as suggested by Ref. [7] (p. 2633), 
"Corporate social responsibility has been a fixture in the business world for decades, and has become embedded in many universities as higher education leaders seek alternative ways to sustainability."

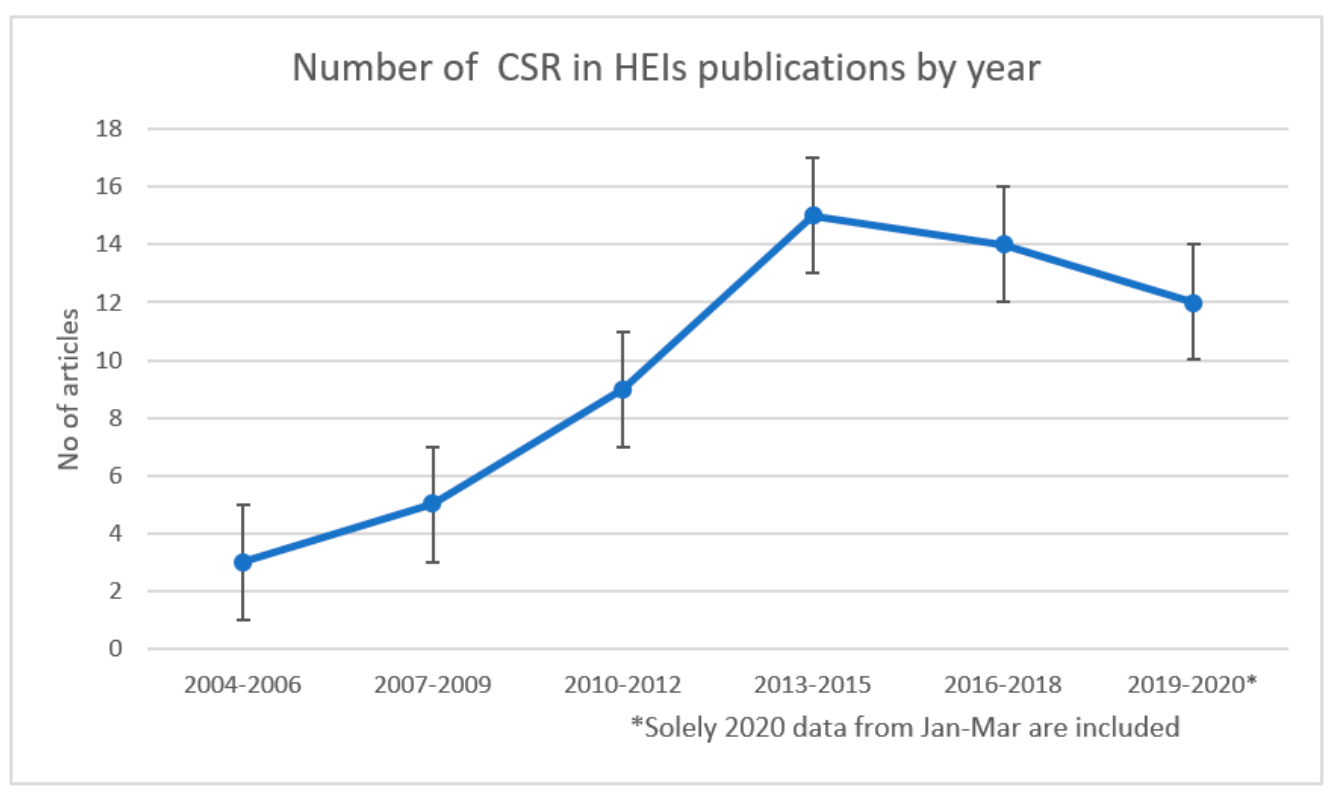

Figure 2. Number of CSR in HEIs' publications studies per year.

It is worth mentioning that our analysis for all articles from 2004-2020 shows that the highest proportion of studies $(67.66 \%)$ focus on the CSR implications throughout university curriculum analysis, CSR knowledge implementation in employment, the integration of ethics, CSR and sustainability, and HEIs' curriculum development based on students work and experience observations, including field trips.

\subsection{The Primary Focus of CSR Studies in HEIs}

As depicted in Figure 3, the articles of this review were classified into three themes to facilitate the analysis within the selected timeframe and databases of the study. Most of the articles found in this review discussed the CSR implications for the HEIs curriculum, CSR disclosure in terms of ethics and social value, and the integration of ethics, CSR and sustainability. Others focused on CSR in action as an interaction of CSR and entrepreneurship. With respect to the theme of CSR's implications and disclosure, twenty-seven articles published during 2004-2020 were focused on teaching initiatives, assessments and research $(n=11)$, the inclusion of ethics, CSR, sustainability and barriers of implication $(n=10)$, and the relationship between a firm's CSR practice and corporate effectiveness and student attractiveness $(n=6)$. In contrast, twenty-four articles published during the study period were based on CSR reporting and disclosure as an interaction of CSR, altruistic motives towards socioeconomic development, ethics, and the enhancement of sustainable development $(n=20)$, and the role of quality management and the accountant as regards reporting $(n=4)$. Furthermore, just seven articles have been published during the study period were focused on CSR into action, and covered CSR project analysis and the interaction of CSR and entrepreneurship. These results are comprehensively in line with the results revealed by Ref. [51], who provided an SLR of sustainability reporting in HEIs during the 2000-2014 study period, whereas Ref. [24] investigated the higher prevalence of general university curriculum analysis during the review of sustainable development in HEIs in the 2005-2014 study period. The evidence concludes that the ethics, sustainability and CSR curricula analysis topics were more prevalent than CSR disclosure and CSR in practice in HEIs. 


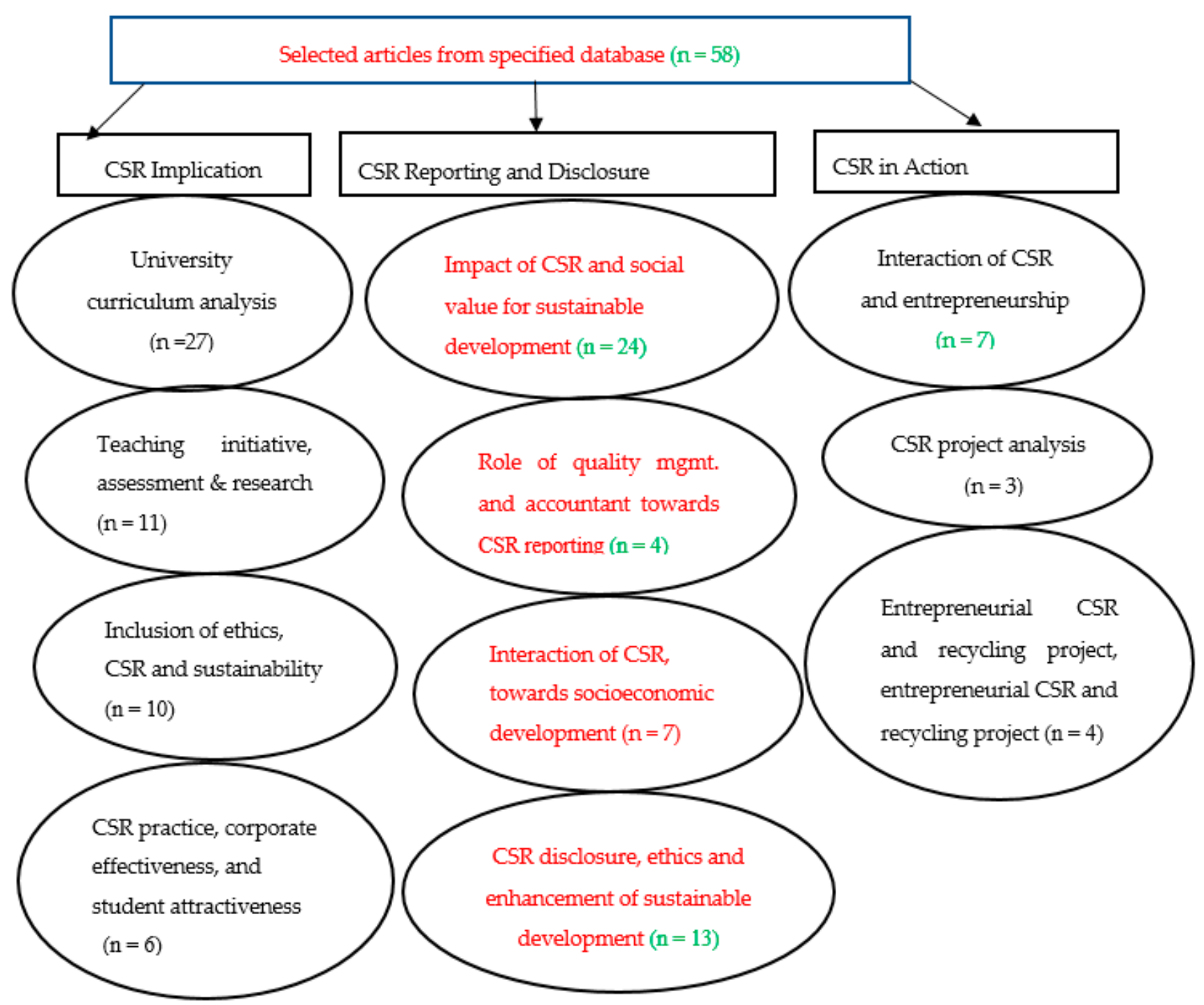

Selected articles from specified database $(n=58)$

Figure 3. Primary focus of CSR studies.

\subsection{Articles per Geographical Region}

In the context of articles distributed in geographical regions, Figure 4 shows that the highest number of research articles were international, at 19\%. Likewise, the USA ranked as the second highest region (12\%) and Europe, Asia and Spain obtained the attention of CSR researchers in HEIs, scoring $8.62 \%$. In contrast, $7 \%$ of CSR research related to HEIs was based on Malaysia. Moreover, 3.44\% of CSR studies originated in Turkey, Nigeria, Taiwan, Lebanon, Switzerland and Pakistan. Besides this, fifteen countries were explored just once in sixteen years. This indicates that universities are encouraged to improve their information transparency and accountability, CSR implications, reporting and disclosure [27,52-55]. Thus, this review recommends that European countries be explored further, with comparisons with the countries situated in other continents. Interestingly, the USA had a slightly higher rate of CSR investigation through questionnaire and content analysis methods. 


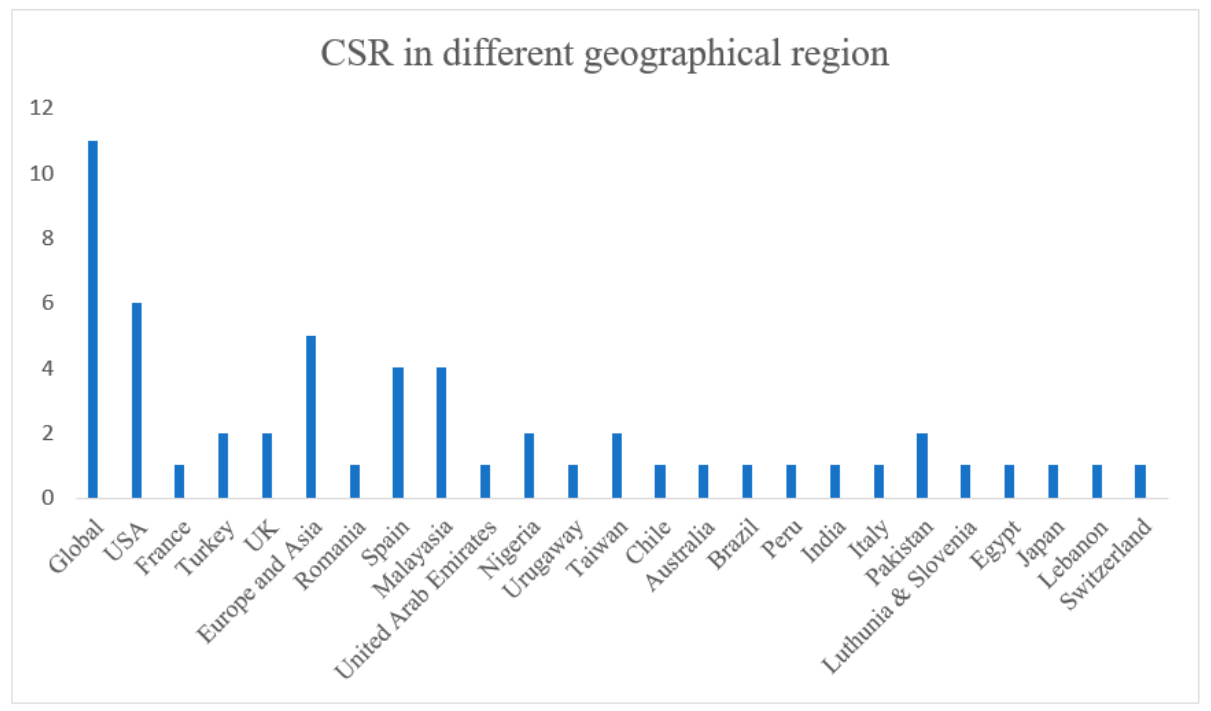

Figure 4. Articles per geographical region.

\subsection{Methods Used to Conduct CSR Research}

The SLR results reveal that the CSR study was predominantly carried out based on quantitative techniques via questionnaires. These results are inconsistent with the SLRs performed by Refs. [30,56-59].

As presented in Figure 5, when we investigated all the quantitative studies, and the results showed in that most of them were carried out through questionnaires, web content analyses and surveys of CSR report analyses. However, these studies may have limited evidence and incomplete results, as questionnaires and content analysis cannot interrogate and provide the reasons behind CSR implication and disclosure [35,60-63]. In contrast, qualitative studies and action research explore in-depth information [30,64]. Few research articles employed mixed methods, particularly the consolidation of interviews and web content analysis, and few studies were based on action research with implications for CSR curriculum and framework development. However, the action research results have a considerable gap in terms of generalization due to their small coverage of data, which is mainly aimed at improving the efficiency of practice rather than efficacy and effectiveness [65]. Even though multi-method research was prevalent in the social sciences, CSR studies in HEIs mainly depend on a qualitative or quantitative method $[7,64,66]$. This has led to the argument that there is a lack of depth in this research field. In this context, mixed methods interact with qualitative and quantitative methods as a third research paradigm to provide complete, balanced and useful results, and are recommended $[67,68]$.

\subsection{Data Sources of CSR in HEIs}

In terms of data collection sources, the researchers administrated questionnaires with students, managers, deans and directors (SMDD) as a source to access CSR's implications in HEIs. Additionally, the Global Reporting Initiatives (GRI) guidelines were adopted as a tool for preparing the questionnaires to investigate the coherence of those guidelines, and assess participants' perceptions regarding the CSR heavily employed in HEIs [65-68]. Content analysis of website information was employed to raise student awareness of how corporate CSR activities can impact national and international social, political, and cultural landscapes, presenting an abundance of CSR articles in HEIs, and these results are in line with those of an SLR on sustainability reporting in HEIs carried out by Ref. [69]. The lesser focus on multiple sources of data collection was different from university to university. However, the majority of researchers investigated how students understood CSR's implication in HEIs. More interestingly, the review reveals that CSR in HEIs was explored from the perspective of stakeholder theory, as HEIs' strategy, value and performance activities were centered on stakeholders (mainly students, society and environment). 


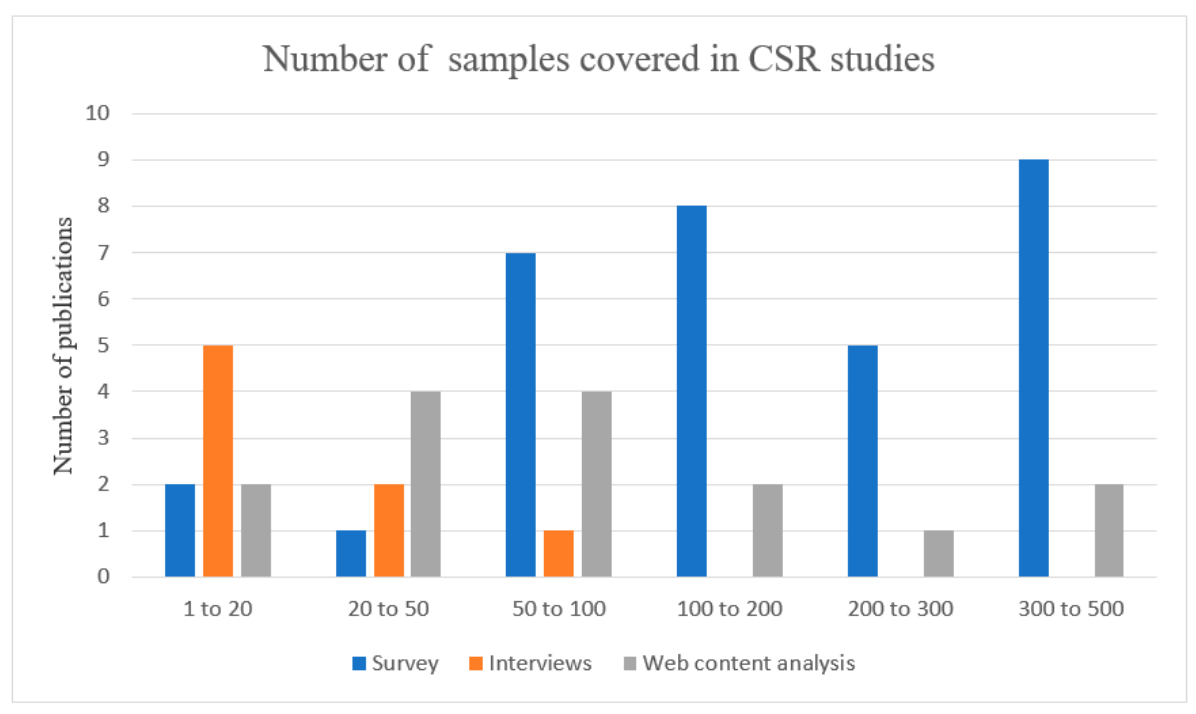

Figure 5. Sample size of CSR studies.

\section{Critical Analysis of the SLR}

The next section of this review covers the research variable employed in prior CSR studies, and the emerging issues and limitations of earlier CSR studies, which were analyzed as the major factors measured in CSR studies in HEIs.

\subsection{Research Factors Affecting CSR Implications and Disclosure in Prior HEIs Studies}

According to Table 1 many previous studies have attempted to explore the factors affecting CSR implication and disclosure. In this vein, most of the earlier studies pointed to some factors that might have some significant influence on CSR implications. These factors are changing awareness, civil society, CSR and sustainability education, the integration of ethics, CSR and sustainability curriculum, standalone ethics, sustainability curriculum, and social entrepreneurship and CSR. This is in line with earlier SLRs, e.g., Refs. [42,70-72], who suggested that the role of business schools is crucially important to promote CSR in practice through teaching, learning and research to promote sustainable development. In this vein, the HEIs' business operations, value proportion, the practice of environmentally focused CSR, marketing strategies, corporate culture, and communication with stakeholders were additional factors which significantly impact CSR's implications. Various studies (e.g., Refs. $[68,70,71])$ were investigated for the changing awareness of civil society, CSR and sustainability education. These studies concluded that the extent of CSR in the HEIs curriculum, and the integration of CSR into teaching, have a crucial influence on CSR's implications, including ethics. In addition, the motivation behind CSR disclosure, the relationship between QMS and CSR in HEIs, the validation and measurement of CSR scale, and the drivers of CSR reporting, are the most crucial factors of CSR disclosure in the HEIs sector. This result is in line with the recommendation of Ref. [24], who explored HEIs' need to undergo a deep transformation of CSR reporting and disclosure for long-term success.

Besides this, another group of studies e.g., $[7,59,72]$ suggested that demographic information, awareness of CSR disclosure, job satisfaction, organizational commitment, CSR voluntary work, desired education for students and value-chain society were the essential factors of graduate perspectives on CSR, which significantly linked the CSR implications within HEIs. Furthermore, technology implementation and social entrepreneurship were other crucial parts of CSR reporting.

In terms of CSR disclosure in HEIs, some factors, such as environmental protection, the social commitment of HEIs, stakeholder engagement, reputation protection, organizational governance, human resource development, critical analysis of ethics and CSR, ethics contradiction and dilemmas, environment-friendly concepts, and legal and ethical responsibilities, were the crucial influences on CSR disclosure in HEIs. 
Table 1. Research factors' effects on CSR's implications and disclosure in prior studies.

\begin{tabular}{cc}
\hline Factors of CSR Implication & Proponents \\
\hline Changing awareness of civil society, CSR and sustainability education & $1,6,14,19,20,23,29,2$ \\
\hline Integration of ethics, CSR and sustainability & $3,4,6,42,51,56,57,58$ \\
\hline The extent of standalone ethics, CSR and sustainability education & $9,24,55$ \\
\hline Social entrepreneurship and CSR, graduates' perceptions of CSR practice & $16,34,5,11,12,15,17,27,41,49,46,57,54$ \\
\hline Factors of CSR disclosure & Proponents \\
\hline The motivation behind CSR disclosure & $52,53,10,13,8$ \\
\hline Relationship between QMS and CSR in HEIs, validation and & 46,45 \\
\hline Drivers of CSR reporting & $18,21,22,23,25,3539,28,29,33,38,47,46,54,55,56$ \\
\hline
\end{tabular}

\subsection{Emerging Issues from Prior CSR Studies}

Numerous similarities and differences were observed as emerging issues in prior CSR studies within the HEIs sector. In this context, many articles explore the significance of CSR curricula improvement in order to prepare socially responsible educated citizens (see Table 2).

Table 2. Emerging issues from prior CSR studies.

\begin{tabular}{ccc}
\hline & Issues Emerging in the Articles & No of Articles \\
\hline Urgency of CSR curricula improvement to produce socially aware and responsible educated citizens & 16 \\
\hline HEIs have little commitment to disclosing CSR information and this is not considered appropriately & 7 & 18 \\
\hline Ethics, CSR and sustainability should be integrated within university degree curricula & 21 \\
\hline Student involvement via socially, ethically minded clubs is a potential driver of changes & 4 \\
\hline $\begin{array}{c}\text { Personal and professional factors, teaching and administrative factors, and inter-personal factors are the } \\
\text { specific barriers to the collaborative teaching of CSR }\end{array}$ & 22 \\
\hline $\begin{array}{c}\text { Public and private status, program size, student's age, students' feedback, knowledge of CSR, students' } \\
\text { and academics' perception and national culture are the primary drivers of CSR implication in HEIs }\end{array}$ & \\
\hline
\end{tabular}

A substantial number of articles $(25 \%)$ revealed that student involvement in a socially, ethical minded club was a potential driver of social change. This result is in alignment with the results announced by Ref. [36], wherein the authors found that internal stakeholders were the key drivers of CSR's implication within the energy sector. In contrast, a similar scale of articles (24\%) concluded that the status of the HEI, program size, the perception of students, and the academic and national culture were the primary drivers of CSR implications and disclosure. This is consistent with the review conducted by Ref. [73] within SMEs. In addition, $20 \%$ of the articles attempted to integrate ethics, CSR and sustainability within the core curriculum. Likewise, other articles (18.18\%) raised the issue that HEIs should urgently improve CSR curriculum to produce socially aware and responsible educated citizens. Finally, several articles claimed that HEIs do not have an appropriate CSR information disclosure commitment. In contrast, $7.40 \%$ of the articles pointed out that the personal and professional, teaching and organizational, and interpersonal factors were the significant barriers to CSR implication.

\subsection{Limitation of Prior Studies and Further Recommendation for CSR Research}

The next focus of this review was to figure out the limitations of CSR research within the HEIs sector. Scholars self-reporting the limitations of their research field may be an essential indicator for future research [74,75]. Table 3 demonstrates the limitations explained by selected articles from various databases. The major limitation highlighted by most CSR 
articles $(26.15 \%)$ was the sample size. This correlates to the issue of internal validity, and results in generalization across time, setting and individuals $[39,43,75]$. In addition, due to the small size, the research could not reveal the actual CSR reporting practice, and the entity that regularly publishes on CSR does not reflect the overall CSR practice within the sector/country investigated [16,76]. This was followed by the analysis of documents only, rather than the adoption of an in-depth investigation, as a limitation. Therefore, the consideration of large-scale data is crucial for future researchers.

Table 3. Limitations of prior CSR studies.

\begin{tabular}{cc}
\hline Limitation Highlighted & No of Articles \\
\hline Small sample size used in CSR studies within the HEIs sector & 17 \\
\hline HEIs CSR curriculum just covers the basic information employed as the elective subject rather than the core curriculum & 5 \\
\hline Subjectivity in interview, external validity of qualitative method, and bias in selection of respondents' backgrounds & 5 \\
\hline CSR was examined using one source only, e.g., a website or questionnaires, and information published on a \\
webpage may change quickly
\end{tabular}

In this vein, many prior researchers highlighted the short-term period of their studies, as these were less comprehensive for CSR. As a result, a clear and concise picture of CSR's implications and its disclosure by HEIs might not be represented [32]. More surprisingly, numerous articles (18.84\%) did not highlight research limitations, which means either they did not have any known restrictions or they were hesitant to share the boundaries of their research.

A further focus of this review was to explore the recommendations given by previous researchers.

Many prior researchers suggested performing in-depth case studies to find out the drivers behind CSR implications and disclosure (see Table 4, seventeen times each), and carrying out comparative studies to derive cross-sectional and cross-national data (sixteen times). The review revealed that prior studies suggested the employment of various communication channels, such as websites, social media, annual reports and CSR reports (twelve times), to investigate the possible differences and difficulties in CSR implementation within HEIs. Some prior researchers recommended the revision and re-evaluation of the university CSR curriculum, in order to examine where they are tackling current social needs. On the other hand, ten previous researchers suggested that the performance of web content analysis as a longitudinal study, and the good practices of lectures and learners quality performance, should be investigated.

Table 4. Recommendation highlighted by prior studies.

\begin{tabular}{|c|c|}
\hline Further Research Suggestions & No of Articles \\
\hline $\begin{array}{l}\text { University curriculum should be researched and revised as core curriculum in an individual subject area } \\
\text { (e.g., accounting or management) }\end{array}$ & 9 \\
\hline Comparative studies as cross-sectional and cross-national & 16 \\
\hline Web-page content analysis should be employed as a longitudinal CSR study & 10 \\
\hline Good practice of HEIs lecturers and learner quality performance should be explored & 10 \\
\hline In-depth case study needed to establish the main drivers of CSR implication, reporting and disclosure & 17 \\
\hline $\begin{array}{l}\text { Studies should be focused on other channels of investigation (e.g., social media, CSR report, annual report, } \\
\text { or website) }\end{array}$ & 12 \\
\hline
\end{tabular}




\section{Conclusions and Recommendations for Future Research}

The main purpose of this SLR has been to review the most up to date research on CSR in HEIs in order to identify what we know and do not know about the CSR implication and disclosure practices of HEIs around the world. Our SLR analyzed 58 studies in 9 major databases from 2004 to 2020. This SLR contributes to the topic in several ways, summarizing the extent and trend of CSR implication and disclosure practices, whereby we find that the extent and trend of the CSR implication and reporting practice has increased an insignificant amount, cohering with Refs. [63,74]. However, this review encourages future researchers to explore the identified areas and the uncovered geographical regions. Even though many researchers increased their attention on CSR studies in HEIs, as shown in Figure 4, CSR implementation in HEIs is not investigated in many developing and developed countries [9,35,57].

In this regard, the factors affecting CSR implication and disclosure are still open for more detailed study. Therefore, we emphasize the need for longitudinal studies, as there is still a considerable gap in HEIs CSR practices. This result is in line with other reviews $[14,43,58,59,77]$.

Furthermore, to explore CSR at a comprehensive level, more qualitative and quantitative studies, wherein stakeholders' engagement outcomes for the CSR curriculum, CSR's implications, and HEIs' performance and disclosure, could be investigated. Various avenues for future research currently remain open. For example, most of the CSR studies in HEIs are empirical in nature, and triangulation with the theoretical ground is still lacking. This review indicates that most of the research was based on questionnaires and the examination of HEIs' curricula, and the focus should be on studying the CSR process rather than CSR outcomes. In this regard, this SLR suggests that theoretical integration with the empirical studies will help further researchers to explore the CSR implication in different legislation of HEIs, and consistent with Refs. [43,78].

In addition, this review shows that prior researchers heavily employed a single method of CSR study in HEIs. So, there is ample space for multiple processes and multilevel studies where a GRI, integrated reporting framework, and integrated thinking approach can be implemented as a newly developed reporting framework [1,2,79]. This is consistent with earlier reviews $[32,59]$. Moreover, different role models in CSR studies in HEIs, who are mainly students, course directors, department heads and managers, have consistently participated in CSR studies; however, the increasing role of university management, academics, communities, government, policymakers and regulators are primarily ignored by scholars, and are also explored in the CSR review by Refs. [14,43,80-83].

Lastly, the Journal of Business Ethics and Corporate Social Responsibility is seen as the most influential journal for CSR studies in HEIs. In this regard, Special Issues on an unexplored area could highlight under-researched themes. Furthermore, CSR implication and disclosure could be beneficial in tackling the different crises, in terms of the financial crisis, long-term survival, maintaining organizational reputation, differentiating the organization, innovation and stakeholders' engagement, and transforming the fundamental values of HEIs into an advantageous position, can be done through CSR [82-84]. In addition, to minimize the ongoing uncertainty of COVID-19, HEIs should be collectively engaged with stakeholders for long-term value creation, and decision-making by governing bodies should focus on sustainable development as an integral part of society.

As with all other research, our SLR has some limitations. In order to make a clear path for the systematic review, only peer-reviewed articles were included. While other official documents, such as a survey from a professional body (ACCA, CIMA, CPA), study reports of independent policy makers (British Funding Council, BUFDG), book chapters and postgraduate research dissertations, may have given CSR consideration, these were not included in this SLR. The use of significant search terms is another limitation; "CSR in HEIs", "CSR practice in HEIs" and "CSR disclosure" were the fundamental items of terminology used to search the related journal articles in the specific databases. Therefore, prior CSR studies in HEIs which did not cover the above terminology were 
excluded from this study arbitrarily. The study period is another limitation of this SLR, as it includes articles published from the period of 2004-2020; papers published after March 2020 were excluded. The source of the articles used in this review is another limitation, because those articles which were not published in the selected databases (namely JSTOR, Taylor and Francis, Social Sciences Citation Index (SSCI), Science Direct, Sage Journals, Emerald, Springer Link, SCOPUS and Wiley Library) were excluded. We suggest that future researchers might include all the excluding factors as new dimensions for potential research.

In this SLR, indicators of CSR studies have been embedded with the existing CSR studies (see Table 2) as the variables integrated into CSR studies; for example, "CSR disclosure and organizational attraction", "motivation of CSR adoption", "internal CSR practice", "commitment of CSR education", "integration of CSR into teaching and research", and "standalone or embedded CSR subjects", were mainly implicated in practice, and have not been fully explained in the literature. This could suggest that some exciting variables may have been researched further.

Author Contributions: Conceptualization, M.A., A.H. and B.S.; methodology, M.A. and A.H.; validation, M.A., A.H. and B.S.; formal analysis, M.A. and A.H.; investigation, M.A. and A.H.; resources, M.A. and A.H.; data curation, M.A., A.H. and B.S.; writing-original draft preparation, M.A. and A.H.; writing-review and editing, M.A., A.H. and B.S.; visualization, M.A., A.H. and B.S.; supervision, A.H. and B.S.; project administration, M.A., A.H. and B.S. All authors have read and agreed to the published version of the manuscript.

Funding: This research received no external funding.

Institutional Review Board Statement: Not applicable.

Informed Consent Statement: Not applicable.

Conflicts of Interest: The authors declare no conflict of interest. 


\section{Appendix A}

Table A1. Reference list of articles.

\begin{tabular}{|c|c|c|c|c|}
\hline No & Year & Name of Journal & Research Sample & Data Source \\
\hline 1 & 2004 & Journal of Business Ethics & 166 surveys one year & Online survey from head of school, deans, course directors and researchers in HEIs \\
\hline 2 & 2004 & $\begin{array}{c}\text { International Journal of } \\
\text { Sustainability in Higher Education }\end{array}$ & $\begin{array}{l}\text { Accounting Course analysis for a } \\
\text { final year undergraduate module }\end{array}$ & $\begin{array}{l}\text { The course was developed within accounting and finance department, } 75 \text { students had taken } \\
\text { the course }\end{array}$ \\
\hline 3 & 2006 & Corporate Governance & 465 Questionnaires, Spring 2005 & $\begin{array}{l}\text { Online survey carried out to obtain students' and young managers' perceptions at Audience } \\
\text { Nantes, school of mgmt. and alumni members }\end{array}$ \\
\hline 4 & 2007 & Journal of Business Ethics & 44 online surveys, 2006 & Online survey gathered from Top 50 MBA programs ranked by the Financial Times 2006 \\
\hline 6 & 2007 & Journal of Business Ethics & 6 semi-structured interviews & Semi-structured interviews with mgmt., the director of communications and academics \\
\hline 7 & 2008 & Journal of Business Ethics & $\begin{array}{l}\text { Survey with } 411 \text { managers and } \\
506 \text { students }\end{array}$ & $\begin{array}{l}\text { Questionnaires were administrated with full time undergraduate and managers within } \\
\text { seven universities }\end{array}$ \\
\hline 8 & 2009 & Journal of Education for Business & $\begin{array}{l}\text { Web content analysis for } 74 \\
\text { universities }\end{array}$ & Courses related to NGOs, business and society, CSR and business ethics \\
\hline 9 & 2009 & Journal of Education for Business & 405 questionnaires & $\begin{array}{l}\text { Questionnaires administrated within accounting, finance, mgmt. and marketing department, } \\
\text { descriptive statistics and ANOVA employed for analysis }\end{array}$ \\
\hline 10 & 2010 & Journal of Academic Ethics & $\begin{array}{c}\text { interviews and questionnaires } \\
\text { within } 4 \text { universities and } \\
4 \text { employers }\end{array}$ & $\begin{array}{l}\text { In depth interviews and semi-structured interviews were lasting } 45 \text { to } 60 \mathrm{~min} \text {, all questionnaires } \\
\text { and interviews were analyzed by NVivo } 8\end{array}$ \\
\hline 11 & 2011 & $\begin{array}{l}\text { Journal of Management } \\
\text { and Organization }\end{array}$ & 94 Online surveys, 2007 & $\begin{array}{l}72 \text { surveys from European universities, } 22 \text { from North American continent (Canada and USA) } \\
\text { business school ranked by the Financial Times }\end{array}$ \\
\hline 12 & 2011 & Corporate Social Responsibility & $\begin{array}{l}100 \text { job offers } \\
\text { announcement analysis }\end{array}$ & $\begin{array}{l}\text { Financial and management accountant job offer announcement analysis, descriptive analysis with } \\
\text { XLATAT in excel }\end{array}$ \\
\hline 13 & 2011 & $\begin{array}{l}\text { Journal of Management } \\
\text { and Organization }\end{array}$ & 73 universities web content analysis & HEIs business school's web content and explore standalone or embedded CSR subjects \\
\hline 14 & 2011 & Journal of Business Ethics & $\begin{array}{l}85 \text { questionnaires and } 74 \text { web } \\
\text { analysis and interviews }\end{array}$ & $\begin{array}{l}\text { Survey carried out via questionnaire form for individuals who are engaged in the Business Ethics } \\
\text { field, telephone interviews employed in South East Asia }\end{array}$ \\
\hline 15 & 2011 & $\begin{array}{c}\text { African Journal of } \\
\text { Business Management }\end{array}$ & $\begin{array}{l}10 \text { universities website } \\
\text { analysis, } 2009\end{array}$ & $\begin{array}{c}\text { Content analysis of top } 10 \text { universities' websites from the world ranked by Times Higher } \\
\text { Education (THE 2009) }\end{array}$ \\
\hline
\end{tabular}


Table A1. Cont.

\begin{tabular}{|c|c|c|c|c|}
\hline No & Year & Name of Journal & Research Sample & Data Source \\
\hline 16 & 2012 & $\begin{array}{l}\text { American International Journal of } \\
\text { Contemporary Research }\end{array}$ & $\begin{array}{l}\text { Case study research of Istanbul } \\
\text { Bilgi University }\end{array}$ & Two in-depth interviews were conducted with secretary general and PRME representative \\
\hline 17 & 2012 & Social Responsibility Journal & 150 surveys & Questionnaires collected from undergraduate students in 14 Malaysian universities \\
\hline 18 & 2012 & Journal of Business Ethics & $\begin{array}{l}\text { Third Year undergraduate students' } \\
\text { project analysis }\end{array}$ & $\begin{array}{c}\text { assessment projects are analyzed, which was carried out by third year undergraduate students, } \\
\text { HEIs website analysis and sharing learning experiences about CSR }\end{array}$ \\
\hline 19 & 2013 & $\begin{array}{l}\text { An International } \\
\text { Multidisciplinary Journal }\end{array}$ & 10 interviews & Interviews taken using open-ended questions with Public Relation practitioners in HEIs \\
\hline 20 & 2013 & Journal of Marketing Education & 91 questionnaires & $\begin{array}{l}\text { Online survey targeted at deans and chairs of Marketing departments at AACSB International } \\
\text { accredited schools }\end{array}$ \\
\hline 21 & 2013 & $\begin{array}{l}\text { An International } \\
\text { Multidisciplinary Journal }\end{array}$ & $\begin{array}{l}10 \text { interviews with } \\
\text { open-ended questions }\end{array}$ & Interview carried out with 10 public relations practitioners in Jos, Plateau \\
\hline 22 & 2013 & $\begin{array}{l}\text { Journal of Environmental Policy } \\
\text { and Planning }\end{array}$ & 123 CSR reports analysis & Content analysis of CSR reports, descriptive analysis, GRI guideline adopted \\
\hline 23 & 2013 & $\begin{array}{l}\text { Journal of Scientific Papers } \\
\text { Economics and Sociology }\end{array}$ & Survey with 200 questionnaires & $\begin{array}{l}\text { Questionnaires administration to final year undergraduate students, Business and Economics } \\
\text { department at University of Uruguay }\end{array}$ \\
\hline 25 & 2013 & $\begin{array}{l}\text { International Journal of } \\
\text { Sustainability in Higher Education }\end{array}$ & Survey with 70 questionnaires & Descriptive analysis carried out, SPSS 16.0 was employed for regression analysis \\
\hline 26 & 2014 & $\begin{array}{l}\text { Systemic Practice and } \\
\text { Action Research }\end{array}$ & Canonical action research method & $\begin{array}{l}\text { Undergraduates and postgraduate students were engaged in self learning course of computer } \\
\text { recycling programs (CRP), field observation, } 3 \text { refurbish workshops organized and } 114 \text { computers } \\
\text { refurbished and distributed to the NGOs. }\end{array}$ \\
\hline 27 & 2014 & $\begin{array}{l}\text { International Review on Public and } \\
\text { Non-profit Marketing }\end{array}$ & 400 structured questionnaires & $\begin{array}{c}\text { Questionnaires administrated in social and legal discipline, Arts and humanities, Technical and } \\
\text { Engineering, Health and Experimental Science department }\end{array}$ \\
\hline 28 & 2014 & $\begin{array}{l}\text { Business Ethics: A } \\
\text { European Review }\end{array}$ & $\begin{array}{l}\text { 77-university curriculum analysis } \\
\text { for organizational management } \\
\text { undergraduate courses }\end{array}$ & $\begin{array}{l}\text { Undergraduate degree curriculum was analyzed, content analysis with three indices to quantify } \\
\text { the results }\end{array}$ \\
\hline 29 & 2015 & Journal of Business Ethics & 230 Questionnaires & Questionnaires obtained from MBA program students and program directors \\
\hline 30 & 2015 & Sustainability & $\begin{array}{l}39 \text { universities' web } \\
\text { contents analyzed }\end{array}$ & Data obtained from universities websites, content analysis \\
\hline
\end{tabular}


Table A1. Cont.

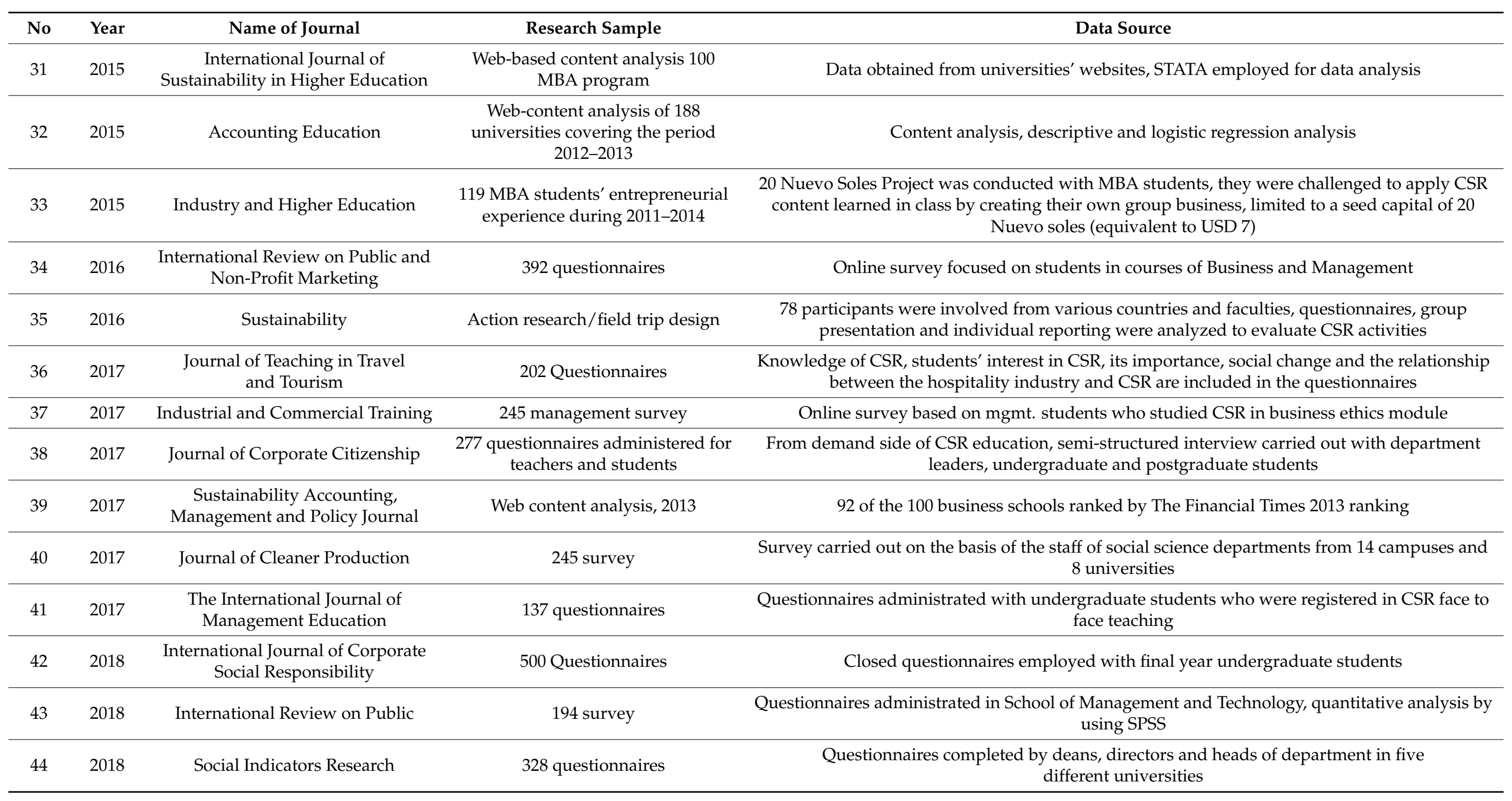


Table A1. Cont.

\begin{tabular}{|c|c|c|c|c|}
\hline No & Year & Name of Journal & Research Sample & Data Source \\
\hline 45 & 2018 & $\begin{array}{l}\text { Total Quality Management and } \\
\text { Business Excellence }\end{array}$ & Content analysis of ISO website & Content analysis as qualitative technique, NVivo employed for analysis \\
\hline 46 & 2018 & $\begin{array}{c}\text { International Journal of } \\
\text { sustainability in Higher education }\end{array}$ & $\begin{array}{l}\text { Web content analysis of CSR and SR } \\
\text { reports }\end{array}$ & $\begin{array}{l}356 \text { universities, which are the members of the Sustainability Tracking and Assessment and } \\
\text { Rating System (STARS), were included, descriptive analysis carried out }\end{array}$ \\
\hline 47 & 2019 & Quality Assurance in Education & $\begin{array}{l}11 \text { semi-structured interviews } \\
\text { within } 3 \text { Lebanese Business Schools }\end{array}$ & $\begin{array}{l}\text { Interviews were conducted in } 3 \text { Lebanese Business Schools from November } 2016 \text { to August 2017, } \\
\text { NVivo employed for data analysis }\end{array}$ \\
\hline 48 & 2019 & $\begin{array}{l}\text { Inzinerine Ekonomika } \\
\text { Engineering Economics }\end{array}$ & $\begin{array}{l}371 \text { business students } 2017-18 \\
\text { academic year }\end{array}$ & $\begin{array}{c}\text { Online survey targeted at business students from the faculties of business mgmt. and economics } \\
\text { and business }\end{array}$ \\
\hline 49 & 2019 & $\begin{array}{l}\text { The International Journal of } \\
\text { Management Education }\end{array}$ & 86 interviews & $\begin{array}{c}\text { Semi-structured interviews with scholars participated in EGOS Colloquium in Copenhagen and } \\
\text { Congress of the RIODD in Paris }\end{array}$ \\
\hline 50 & 2019 & $\begin{array}{l}\text { Journal of Humanities and Applied } \\
\text { Social Science }\end{array}$ & 35 universities, 2018 & $\begin{array}{c}\text { Universities' website analysis, content analysis with self-developed disclosure index } \\
\text { was employed }\end{array}$ \\
\hline 51 & 2019 & Global Business Review & 107 universities websites & $\begin{array}{l}\text { Web-based content analysis and exploration of MBA program courses related to CSRs, special } \\
\text { degree program of CSR curricula centers to support CSR-based activities }\end{array}$ \\
\hline 52 & 2019 & $\begin{array}{l}\text { Journal of The Japanese and } \\
\text { International Economics }\end{array}$ & 6897 web-based analyses, July 2019 & Web-based survey with CSR measures, environment, social and governance \\
\hline 53 & 2019 & $\begin{array}{l}\text { Journal of Hospitality, Leisure } \\
\text { Sports and Tourism Education }\end{array}$ & $\begin{array}{l}\text { Experimental and qualitative } \\
\text { research method explored with } \\
4 \text { curriculum developers }\end{array}$ & $\begin{array}{l}\text { CSR curriculum developed, examined its validity and reliability and gathered students' } \\
\text { experience on tourism hospitality }\end{array}$ \\
\hline 54 & 2019 & Sustainability & $\begin{array}{l}\text { Questionnaires and experiment } \\
\text { with } 106 \text { participants }\end{array}$ & $\begin{array}{l}56 \text { participants from Economic and Business Science faculty, } 30 \text { from Education and } 20 \text { from } \\
\text { Philosophy and Arts, the average age of participants was } 25.5 \text { years, } 75.5 \% \text { female and } 25.5 \% \\
\text { male participants were included }\end{array}$ \\
\hline 55 & 2019 & Sustainability & $\begin{array}{l}3 \text { MBA case studies and } \\
12 \text { interviews }\end{array}$ & $\begin{array}{c}\text { All case studies were from the most relevant MBA, ranked in the Financial Times, The Economist } \\
\text { and Bloomberg Businessweek. }\end{array}$ \\
\hline 56 & 2020 & $\begin{array}{l}\text { The International Journal of } \\
\text { Management Education }\end{array}$ & $\begin{array}{l}\text { Survey within } 16 \text { business schools } \\
\text { belonging to the Global Network for } \\
\text { Advanced Management }\end{array}$ & $\begin{array}{c}\text { Survey was based on Sustainability Assessment Questionnaire (SAQ), used to determine the } \\
\text { social responsibility in MBA programs }\end{array}$ \\
\hline 57 & 2020 & Sustainability & $\begin{array}{l}\text { Web content analysis of } 200 \text { top } \\
\text { HEIs ranked in Shanghai Ranking }\end{array}$ & $\begin{array}{l}\text { Impact of corporate governance mechanism on CSR disclosure was highlighted, descriptive } \\
\text { analysis and regression analysis were implemented }\end{array}$ \\
\hline 58 & 2020 & Journal of Business Ethics & 425 questionnaires & $\begin{array}{l}\text { Study population was final year undergraduate students who studied "Business Start-up" to } \\
\text { establish own business }\end{array}$ \\
\hline
\end{tabular}




\section{Appendix B. References Analysed in the SLR}

References are listed on chronological order as per year of publication.

1. Matten, D; Moon, J. Corporate Social Responsibility Education in Europe. Journal of Business Ethics 2004, 54, 323-337.

2. Holland, L. Experiences from a student program designed to examine the role of accountant in corporate social responsibility (CSR). International Journal of Sustainability in Higher Education 2004, 5, 404-416.

3. Sobczak, A.; Debucquet, G.; Havard, C. The impact of higher education on students' and young managers' perception of companies and CSR: an exploratory analysis. Corporate Governance 2006, 6, 463-474.

4. Christensen, L.J.; Peirce, E.; Hartman, L.P.; Carrier, J. Ethics, CSR, and Sustainability Education in the Financial Times Top 50 Global Business Schools: Baseline Data and Future Research Directions. Journal of Business Ethics 2007, 73, 347-368.

5. Cornelius, N.; Wallace, J.; Tassabehji, R. An Analysis of Corporate Social Responsibility, Corporate Identity and Ethics Teaching in Business Schools. Journal of Business Ethics 2007, 76, 117-135.

6. Atakan, M. G. S.; Eker, T. Corporate Identity of a Socially Responsible University: A Case from the Turkish Higher Education Sector. Journal of Business Ethics 2007, 76, $55-68$.

7. Ibrahim, N. A.; Howard, D. P.; Angelidis, J. P. The Relationship between Religiousness and Corporate Social Responsibility Orientation: Are There Differences between Business Managers and Students? Journal of Business Ethics 2008, 78, 165-174.

8. Aytul Ayse Özdemir, A.; Saraiya, M. An Analysis of the Curricula of Business Administration Departments in Turkish Universities with the Perspective of Civil Society Awareness. Journal of Education for Business 2009, 84, 313-317.

9. Nicholson, C. Y.; DeMoss, M. Teaching Ethics and Social Responsibility: An Evaluation of Undergraduate Business Education at the Discipline Level. Journal of Education for Business 2009, 84, 213-218.

10. Gray, B. The Rise of Voluntary Work in Higher Education and Corporate Social Responsibility in Business: Perspectives of Students and Graduate Employees. Journal of Academic Ethics 2010, 8, 95-109.

11. Scjneider, S. C.; Zollo, M.; Manocha, R. Developing Socially Responsible Behaviour in Managers: Experimental evidence of the Effectiveness of Different Approaches to Management Education. The Journal of Corporate Citizenship 2010, 29, 21-40.

12. Moon, J.; Olitzky, M. Corporate social responsibility and sustainability education: A trans-Atlantic comparison. Journal of Management \& Organization 2011, 17, 583-603.

13. Albu, N.; Albu, C. N.; Gîrbină, M. M.; Sandu, M. I. The implications of corporate social responsibility on the accounting profession: The case of Romania. Corporate Social Responsibility 2011, 8, available online: SSRN: https:/ /ssrn.com/abstract=1769956 (accessed 10 March 2020).

14. Setó-Pamies, D.; Rabassa-Figueras, N. Corporate Social Responsibility in Management Education: Current status in Spanish universities. Journal of Management \& Organization 2011, 17, 604-620.

15. Srinivasan, V. Business Ethics in the South and South East Asia. Journal of Business Ethics 2011, 104, 73-81.

16. Nejati, M.; Shafaei, A.; Salamdadeh, Y.; Daraei, M. Corporate social responsibility and universities: A study of top 10 world universities' websites. African Journal of Business Management 2011, 5, 440-447.

17. Dahan, G. S.; Senol, I. Corporate Social Responsibility in Higher Education Institutions: Istanbul Bilgi University Case. American International Journal of Contemporary Research 2012, 2, 95-103.

18. Ahmad, J. Can a university act as a corporate social responsibility (CSR) driver? An analysis. Social Responsibility Journal 2012, 8, 77-86. 
19. Goby, V. P.; Nickerson, C. Introducing Ethics and Corporate Social Responsibility at Undergraduate Level in the United Arab Emirates: An Experiential Exercise on Website Communication. Journal of Business Ethics 2012, 107, 103-109.

20. Asemah, E. S.; Okpanachi, R. A.; Olumuji, E. O. Universities and Corporate Social Responsibility Performance: An Implosion of the Reality. An International Multidisciplinary Journal 2013, 4, 195-224.

21. Nicholls, J.; Hair Jr, J. F.; Ragland, C. B.; Schimmel, K. E. Ethics, Corporate Social Responsibility and Sustainability Education in AACSB Undergraduate and Graduate Marketing Curricula: A Benchmark Study. Journal of Marketing Education 2013, 35, 129-140.

22. Rodríguez Bolívar, M. P.; Sánchez, R. G.; López Hernández, A. M. Online Disclosure of Corporate Social Responsibility Information in Leading Anglo-American Universities. Journal of Environmental Policy \& Planning 2013, 15, 551-575.

23. Vázquez, J. L.; Lanero, A.; Licandro, O. Corporate Social Responsibility and Higher Education: Uruguay University Students' Perceptions. Economics \& Sociology 2013, 6, 145-157.

24. Sánchez, R. G.; Rodríguez Bolívar, M. P.; López-Hernández, A. M. Online disclosure of university social responsibility: a comparative study of public and private US universities. Environmental Education Research 2013, 19, 709-746.

25. Joseph, C.; Obrin Nichol, E.; Janggu, T.; Madi, N. Environmental literacy and attitudes among Malaysian business educators. International Journal of Sustainability in Higher Education 2013, 14, 196-208.

26. Chang, Y.; Chen, Y.; Wang, F.T.; Chen, S.; Liao, R. Enriching Service Learning by its Diversity: Combining University Service Learning and Corporate Social Responsibility to Help the NGOs Adapt Technology to Their Needs. Systematic Practice and Action Research 2014, 27,185-193.

27. Vázquez, J. L.; Aza, C. L.; Lanero, A. Are students aware of university social responsibility? Some insights from a survey in a Spanish university. International Review on Public and Non-profit Marketing 2014, 11, 195-208.

28. Larrán Jorge, M.; Andrades Peña, F. J. Determinants of corporate social responsibility and business ethics education in Spanish universities. Business Ethics: A European Review 2014, 23, 139-153.

29. Koljatic, M.; Silva, M. Do Business Schools Influence Students' Awareness of Social Issues? Evidence from Two of Chile's Leading MBA Programs. Journal of Business Ethics 2015, 131, 595-604.

30. Sánchez, R.G.; Bolívar, M.P.R.; Hernández, A.M.L. Are Australian Universities Making Good Use of ICT for CSR Reporting? Sustainability 2015, 7, 14895-14916.

31. Hart, T.A.; Fox, C.J.; Ede, K.F. and Korstad, J. Do, but don't tell: The search for social responsibility and sustainability in the websites of the top-100 US MBA programs. International Journal of Sustainability in Higher Education 2015,16, 706-728.

32. Larrán Jorge, M.; Andrades Peña, F. J. and Muriel de los Reyes, M. J. Factors Influencing the Presence of Ethics and CSR Stand-alone Courses in the Accounting Masters Curricula: An International Study. Accounting Education 2015, 24, 361-382.

33. Farber, V. A.; Prialé, M. A.; Fuchs, R. M. An entrepreneurial learning exercise as a pedagogical tool for teaching CSR. INDUSTRY \& HIGHER EDUCATION 2015, 29, 345-360.

34. Sánchez-Hernández, M. I.; Mainardes, E. W. University social responsibility: a student base analysis in Brazil. International Review on Public Non-profit Marketing 2016, 13, 151-169.

35. Yoon, T. K.; Kim, S.; Takano, T.; Yun, S. J.; Son, Y. Contributing to Sustainability Education of East Asian University Students through a Field Trip Experience: A SocialEcological Perspective. Sustainability 2016, 8, 1067.

36. Zizka, L. Student perceptions of ethics, CSR, and sustainability (ECSRS) in hospitality management education. Journal of Teaching in Travel \& Tourism 2017,17:4, 254-268, 
37. Saxena, M.; Mishra, D. K. CSR perception: a global opportunity in management education. Industrial and Commercial Training 2017, 49, 231-244.

38. Chirieleison, C. CSR Education in Italian Economics Departments. An Exploratory Study. The Journal of Corporate Citizenship 2017, 65, pp. 12-29.

39. Jorge, M.; Andrades Peña, F.J.; Muriel de los Reyes, M.J. Analysing the inclusion of stand-alone courses on ethics and CSR: A study of the MBA curricula of the Financial Times top-ranked business schools. Sustainability Accounting, Management and Policy Journal 2017, 8, 114-137.

40. Asrar-ul-Haq, M.; Kuchinke, K. P.; Iqbal, A. The relationship between corporate social responsibility, job satisfaction, and organizational commitment: Case of Pakistani higher education. Journal of Cleaner Production 2017, 142, 2352-2363.

41. Burga, R.; Leblanc, J.; Rezania, D. Analysing the effects of teaching approach on engagement, satisfaction and future time perspective among students in a course on CSR. The International Journal of Management Education 2017, 15, 306-317.

42. Simpson, S.N.Y.; Aprim, E.K. Do corporate social responsibility practices of firms attract prospective employees? Perception of university students from a developing country. International Journal of Corporate Social Responsibility 2018, 6, Available online: https:/ / doi.org/10.1186/s40991-018-0031-6 (accessed 15 March 2020).

43. Teixeira, A.; Ferreira, M.R.; Correia, A.; Lima, V. Students' perceptions of corporate social responsibility: evidence from a Portuguese higher education institution. International Review on Public Non-profit Marketing 2018, 15, 235-252.

44. Latif, K. F. The Development and Validation of Stakeholder-Based Scale for Measuring University Social Responsibility (USR). Social Indicators Research 2018, 140, 511-547.

45. Mo-Ching Yeung, S. Linking ISO 9000 (QMS), ISO 26000 (CSR) with accreditation requirements for quality indicators in higher education. Total Quality Management $\mathcal{E}$ Business Excellence 2018, 29, 1594-1611.

46. Sassen, R.; Azizi, L. Assessing sustainability reports of US universities. International Journal of Sustainability in Higher Education 2018, 19, 1158-1184.

47. Chedrawi, C.; Howayeck, P. and Tarhini, A. CSR and legitimacy in higher education accreditation programs, an isomorphic approach of Lebanese business schools. Quality Assurance in Education 2019, 27 70-81.

48. Nedelko, Z.; Peleckiene, V.; Peleckis, K.; Peleckis, K. K.; Lapinskiene, G.; Potocan, V. The Impact of Economic Attitudes on Natural and Social Corporate Responsibility - A Comparative Study of Lithuania and Slovenia. Inzinerine Ekonomika-Engineering Economics 2019, 30, 362-372.

49. Abdul Rahaman, A.; Castka, P.; Love, T. Corporate social responsibility in higher education A study of the institutionalisation of CSR in Malaysian public universities. Corporate Social Responsibility and Environmental Management 2019, 26, 916-928.

50. Ramboarisata, L.; Gendron, C. Beyond moral righteousness: The challenges of nonutilitarian ethics, CSR, and sustainability education. The International Journal of Management Education 2019, 17, 1-12.

51. Ismail, T.H. Does Egyptian universities' disclosure on social responsibility enhance sustainable development? Journal of Humanities and Applied Social Sciences 2019, 2, 81-99.

52. Abdur Rehman, M.; Kashif, M.; Mingione, M. Corporate Social Responsibility and Sustainability (CSRS) Initiatives among European and Asian Business Schools: A Webbased Content Analysis. Global Business Review 2019, 20, 1231-1247.

53. Eiji, Y.; Shunsuke, M.; Yoshiro, T. Male pupils taught by female homeroom teachers show a higher preference for Corporate Social Responsibility in adulthood. Journal of The Japanese and International Economies 2019, 54, Available online: https: / /www. sciencedirect.com/science/article/pii/S0889158319300383 (accessed 12 March 2020).

54. Godos-Díez, J.-L.; Fernández-Gago, R.; Cabeza-García, L. How Does Reciprocity Affect Undergraduate Student Orientation towards Stakeholders? Sustainability 2019, $11,5987$. 
55. Fornes, G.; Monfort, A.; Ilie, C.; Koo, C.K.T.; Cardoza, G. Ethics, Responsibility, and Sustainability in MBAs. Understanding the Motivations for the Incorporation of ERS in Less Traditional Markets. Sustainability 2019, 11, 7060.

56. Horng, J.; Hsu, H.; Tsai, C. Learning corporate ethics and social responsibility: Developing an influential curriculum for undergraduate tourism and hospitality students. Journal of Hospitality, Leisure, Sport \& Tourism Education 2019, 24, 100-109.

57. Sánchez, R. G.; Flórez-Parra, J. M.; López-Pérez, M. V.; López-Hernández, A. M. Corporate Governance and Disclosure of Information on Corporate Social Responsibility: An Analysis of the Top 200 Universities in the Shanghai Rank. Sustainability 2020, $12,1549$.

58. Garcia-Morales, V. J.; Martin-Rojas, R.; Garde-Sanchez, R. How to Encourage Social Entrepreneurship Action? Using Web 2.0 Technologies in Higher Education Institutions. Journal of Business Ethics 2020, 161, 329-350.

\section{References}

1. Adams, C. Let's Talk Value: How Universities Create Value for Students, Staff and Society. Available online: www.lfhe.ac.uk (accessed on 6 March 2020).

2. Hassan, A.; Adhikariparajuli, M.; Fletcher, M.; Elamer, A.A. Integrated Reporting in UK Higher Education Institutions. Sustain. Account. Policy J. 2019, 10, 844-876. [CrossRef]

3. Dahan, G.S.; Senol, I. Corporate social responsibility in higher education institutions: Istanbul Bilgi University case. Am. Int. J. Contemp. Res. 2012, 2, 95-103.

4. Gao, L.; Brink, A.G. Whistleblowing studies in accounting research: A review of experimental studies on the determinants of whistleblowing. J. Account. Lit. 2017, 38, 1-13. [CrossRef]

5. Nejati, M.; Shafaei, A.; Salamzadeh, Y.; Daraei, M. Corporate social responsibility and universities: A study of top 10 world universities' websites. Afr. J. Bus. Manag. 2011, 5, 440-447.

6. Binsawad, M.; Sohaib, O.; Hawryszkiewycz, I. Factors impacting technology business incubator performance. Int. J. Innov. Manag. 2019, 23, 1950007-1950030. [CrossRef]

7. Ismail, Z.; Shujaat, N. CSR in Universities: A Case Study on Internal Stakeholder Perception of University Social Responsibility. Adv. Soc. Sci. Res. J. 2019, 6, 75-90.

8. Velte, P.; Stawinoga, M. Empirical research on corporate social responsibility assurance (CSRA): A literature review. J. Bus. Econ. 2017, 87, 1017-1066. [CrossRef]

9. de Castro, R.; Jabbour, C.J.C. Evaluating sustainability of an Indian university. J. Clean. Prod. 2013, 61, 54-58. [CrossRef]

10. Rahman, A.A.; Castka, P.; Love, T. Corporate social responsibility in higher education: A study of the institutionalization of CSR in Malaysian public universities. Corp. Soc. Responsib. Environ. Manag. 2019, 26, 916-928. [CrossRef]

11. Guarini, E.; Nidasio, C. CSR Role in Public-Private Partnerships: Models of Governance. Available online: https://ssrn.com/ abstract=2379382 (accessed on 7 March 2020).

12. Gray, R.; Reza, K.; Simon, L. Corporate social and environmental reporting. Account. Audit. Account. J. 1995, 8, 47-77. [CrossRef]

13. Corporate Social Responsibility. Available online: https://scholar.google.com/scholar?start=10\&q=corporate+social+ responsibility+1995\&hl=en\&as_sdt=0,5 (accessed on 10 March 2020).

14. Pisani, N.; Arno Kourula, A.K.; Renske, M. How global is international CSR research? Insights and recommendations from a systematic review. J. World Bus. 2017, 52, 591-614. [CrossRef]

15. Javaid Lone, E.; Ali, A.; Khan, I. Corporate governance and corporate social responsibility disclosure: Evidence from Pakistan. Corp. Gov. Int. J. Bus. Soc. 2016, 16, 785-797. [CrossRef]

16. Gimenez, C.; Tachizawa, E.M. Extending sustainability to suppliers: A systematic literature review. Supply Chain Manag. 2012, 17, 531-543. [CrossRef]

17. Hodinková, M. The benefits of corporate social responsibility introduction in small and medium-size enterprises: A systematic review of the literature. Verslas Teor. Ir Prakt. 2016, 20, 345-352. [CrossRef]

18. Yeung, S.M.C. Linking ISO 9000 (QMS), ISO 26000 (CSR) with accreditation requirements for quality indicators in higher education. Total Qual. Manag. Bus. Excell. 2018, 29, 1594-1611. [CrossRef]

19. Setó-Pamies, D.; Domingo-Vernis, M.; Rabassa-Figueras, N. Corporate social responsibility in management education: Current status in Spanish universities. J. Manag. Organ. 2011, 17, 604-620. [CrossRef]

20. Moharana, S. Corporate social responsibility: A study of selected public sector banks in India. Iosr J. Bus. Manag. 2013, 15, 1-9. [CrossRef]

21. Nadeem, A.; Kakakhel, S.J. An investigation into corporate social responsibility (CSR) of public sector universities in KPK. Abasyn J. Soc. Sci. 2012, 5, 14-27.

22. Sangle, S. Critical success factors for corporate social responsibility: A public sector perspective. Corp. Soc. Responsib. Environ. Manag. 2010, 17, 205-214. [CrossRef] 
23. Hayter, C.S.; Cahoy, D.R. Towards a strategic view of higher education social responsibilities: A dynamic capabilities approach. Strateg. Organ. 2018, 16, 12-34. [CrossRef]

24. García-Feijoo, M.; Eizaguirre, A.; Rica-Aspiunza, A. Systematic Review of Sustainable-Development-Goal Development in Business Schools. Sustainability 2020, 12, 440. [CrossRef]

25. Setó-Pamies, D.; Papaoikonomou, E. Sustainable Development Goals: A Powerful Framework for Embedding Ethics, CSR, and Sustainability in Management Education. Sustainability 2020, 12, 1762. [CrossRef]

26. Fornes, G.; Monfort, A.; Ilie, C.; Koo, C.K.T.; Cardoza, G. Ethics, Responsibility, and Sustainability in MBAs. Understanding the Motivations for the Incorporation of ERS in Less Traditional Markets. Sustainability 2019, 11, 7060. [CrossRef]

27. Holland, L. Experiences from a student program designed to examine the role of accountant in corporate social responsibility (CSR). Int. J. Sustain. High. Educ. 2004, 5, 404-416. [CrossRef]

28. Godos-Díez, J.-L.; Fernández-Gago, R.; Cabeza-García, L. How Does Reciprocity Affect Undergraduate Student Orientation towards Stakeholders? Sustainability 2019, 11, 5987. [CrossRef]

29. Ferrero-Ferrero, I.; Fernández-Izquierdo, M.Á.; Muñoz-Torres, M.J.; Bellés-Colomer, L. Stakeholder engagement in sustainability reporting in higher education: An analysis of key internal stakeholders' expectations. Int. J. Sustain. High. Educ. 2018, 19, 313-336. [CrossRef]

30. Oll, J.; Rommerskirchen, S. What's wrong with integrated reporting? A systematic review. Sustain. Manag. Forum 2018, 26, 19-34. [CrossRef]

31. Kirca, A.H.; Attila, Y. The use of meta-analysis in international business research: Its current status and suggestions for better practice. Int. Bus. Rev. 2016, 19, 306-314. [CrossRef]

32. Fifka, M.S. Corporate Responsibility Reporting and its Determinants in Comparative Perspective-A Review of the Empirical Literature and a Meta-analysis. Bus. Strategy Environ. 2013, 22, 1-35. [CrossRef]

33. Peloza, J.; Jingzhi, S. How can corporate social responsibility activities create value for stakeholders? A systematic review. J. Acad. Mark. Sci. 2011, 39, 117-135. [CrossRef]

34. Postel, N.; Rousseau, S. CSR and Corporate Ethics: What Institutions Need. Management 2008, 11, 137-160.

35. Agudelo, M.A.L.; Johannsdottir, L.; Davidsdottir, B. Drivers that motivate energy companies to be responsible. A systematic literature review of Corporate Social Responsibility in the energy sector. J. Clean. Prod. 2020, 247, 119094. [CrossRef]

36. Okoli, C. A Critical Realist Guide to Developing Theory with Systematic Literature Reviews. Available online: https://papers. ssrn.com/sol3 / papers.cfm?abstract_id=2115818 (accessed on 25 March 2020).

37. Fink, A. Conducting Research Literature Reviews from the Internet to Paper, 5th ed.; Sage Publication: London, UK, 2019.

38. Stechemesser, K.; Guenther, E. Carbon accounting: A systematic literature review. J. Clean. Prod. 2012, 36, 17-38. [CrossRef]

39. Hahn, R.; Kühnen, M. Determinants of sustainability reporting: A review of results, trends, theory, and opportunities in an expanding field of research. J. Clean. Prod. 2013, 59, 5-21. [CrossRef]

40. Hahn, T.; Pinkse, J.; Preuss, L.; Figge, F. Tensions in Corporate Sustainability: Towards an Integrative Framework. J. Bus. Ethics 2015, 127, 297-316. [CrossRef]

41. Alhossini, M.A.; Ntim, C.; Zalata, A. Corporate Board Committees and Corporate Outcomes: An International Systematic Literature Review and Agenda for Future Research. Int. J. Account. 2020. [CrossRef]

42. Latif, K.F.; Sajjad, A. Measuring corporate social responsibility: A critical review of survey instrument. Corp. Soc. Responsib. Environ. Manag. 2018, 25, 1174-1197. [CrossRef]

43. Khan, M.; Hassan, A.; Harrison, C.; Tarbert, H. CSR reporting: A review of research and for future research. Manag. Res. Rev. 2020. [CrossRef]

44. Fatma, M.; Zillur, R. Consumer Perspective on CSR Literature Review and Future Research Agenda. Manag. Res. Rev. 2015, 38, 195-216. [CrossRef]

45. Wigmore-Álvarez, A.; Ruiz-Lozano, M. University social responsibility (USR) in the global context: An overview of literature. Bus. Prof. Ethics J. 2012, 31, 475-498. [CrossRef]

46. Plöckinger, M.; Aschauer, E.; Hiebl, M.R.W.; Roman, R. The Influence of Individual Executives on Corporate Financial Reporting: A Review and Outlook from the Perspective of Upper Echelons Theory. J. Account. Lit. 2016, 37, 55-75. [CrossRef]

47. Ngai, E.W.T. Customer Relationship Management Research (1992-2002). Mark. Intell. Plan. 2005, 23, 582-605. [CrossRef]

48. Brewerton, P.; Millward, L. Organisational Research Methods; Sage Publication: London, UK, 2011.

49. Zizka, L. Student perceptions of ethics, CSR, and sustainability (ECSRS) in hospitality management education. J. Teach. Travel Tour. 2017, 17, 254-268. [CrossRef]

50. Holtbrügge, D.; Dögl, C. How international is corporate environmental responsibility? A literature review. J. Int. Manag. 2012, 18, 180-195. [CrossRef]

51. Ceulemans, K.; Molderez, I.; Van Liedekerke, L. Sustainability reporting in higher education: A comprehensive review of the recent literature and paths for further research. J. Clean. Prod. 2015, 106, 127-143. [CrossRef]

52. Ntim, C.; Soobaroyen, T.; Broad, M.J. Governance structures, voluntary disclosures and public accountability: The case of UK higher education institutions. Account. Audit. Account. J. 2017, 30, 65-118. [CrossRef]

53. Hart, T.A.; Fox, C.J.; Ede, K.F.; Korstad, J. Do, but don't tell: The search for social responsibility and sustainability in the websites of the top-100 US MBA programs. Int. J. Sustain. High. Educ. 2015, 16, 706-728. [CrossRef] 
54. Larrán Jorge, M.; Andrades Peña, F.J.; Muriel de los Reyes, M.J. Factors Influencing the Presence of Ethics and CSR Stand-alone Courses in the Accounting Masters Curricula: An International Study. Account. Educ. 2015, 24, 361-382. [CrossRef]

55. Chedrawi, C.; Howayeck, P.; Tarhini, A. CSR and legitimacy in higher education accreditation programs, an isomorphic approach of Lebanese business schools. Qual. Assur. Educ. 2019, 27, 70-81. [CrossRef]

56. $\mathrm{Wu}, \mathrm{Y}$.-C.J.; Shen, J.-P. Higher education for sustainable development: A systematic review. Int. J. Sustain. High. Educ. 2016, 17, 633-651. [CrossRef]

57. Sánchez, P.E.; Benito-Hernández, S. CSR policies: Effects on labor productivity in Spanish micro and small manufacturing companies. J. Bus. Ethics 2015, 128, 705-724. [CrossRef]

58. Chen, Y.; Xiao, G.; Yang, W. Optimizing partitioned CSR-based SpGEMM on the Sunway TaihuLight. Neural Comput. Appl. 2020, 32, 5571-5582. [CrossRef]

59. Ortiz-Avram, D.; Domnanovich, J.; Kronenberg, C.; Scholz, M. Exploring the integration of corporate social responsibility into the strategies of small-and medium-sized enterprises: A systematic literature review. J. Clean. Prod. 2018, 201, 254-271. [CrossRef]

60. Gray, R.; Milne, M.J. It's not what you do, it's the way that you do it? Of method and madness. Crit. Perspect. Account. 2015, 32, 51-66. [CrossRef]

61. Asemah, E.S.; Okpanachi, R.A.; Olumuji, E.P. Universities and corporate social responsibility performance: An implosion of the reality. Afr. Res. Rev. 2013, 7, 195-224. [CrossRef]

62. Kemmis, S. Participatory action research and the public sphere. Educ. Action Res. 2006, 14, 459-476. [CrossRef]

63. Garcia-Morales, V.J.; Martin-Rojas, R.; Garde-Sanchez, R. How to Encourage Social Entrepreneurship Action? Using Web 2.0 Technologies in Higher Education Institutions. J. Bus. Ethics 2020, 161, 329-350. [CrossRef]

64. Johnson, R.B.; Onwuegbuzie, A.J.; Turner, L.A. Toward a definition of mixed methods research. J. Mix. Methods Res. 2007, 1, 112-133. [CrossRef]

65. Watkins, D.; Gioia, D. Mixed Methods Research; Oxford University Press: Oxford, UK, 2015.

66. Nicholls, J.; Hair, J.F.; Ragland, C.B.; Schimmel, K.E. Ethics, Corporate Social Responsibility, and Sustainability Education in AACSB Undergraduate and Graduate Marketing Curricula: A Benchmark Study. J. Mark. Educ. 2013, 35, 129-140. [CrossRef]

67. Moon, J.; Orlitzky, M. Corporate social responsibility and sustainability education: A trans-Atlantic comparison. J. Manag. Organ. 2011, 17, 583-603. [CrossRef]

68. Saxena, M.; Mishra, D.K. CSR perception: A global opportunity in management education. Ind. Commer. Train. 2017, 49, 231-244. [CrossRef]

69. Lozano, R. A holistic perspective on corporate sustainability drivers. Corp. Soc. Responsib. Environ. Manag. 2015, 22, 32-44. [CrossRef]

70. Nicholson, C.Y.; DeMoss, M. Teaching ethics and social responsibility: An evaluation of undergraduate business education at the discipline level. J. Educ. Bus. 2009, 84, 213-218. [CrossRef]

71. Teixeira, A.; Ferreira, M.R.; Correia, A.; Lima, V. Students' perceptions of corporate social responsibility: Evidence from a Portuguese higher education institution. Int. Rev. Public Nonprofit Mark. 2018, 15, 235-252. [CrossRef]

72. Rodríguez Bolívar, M.P.; Garde Sánchez, R.; López Hernández, A.M. Online disclosure of corporate social responsibility information in leading Anglo-American universities. J. Environ. Policy Plan. 2013, 15, 551-575. [CrossRef]

73. Vázquez-Carrasco, R.; López-Pérez, M.E. Small \& medium-sized enterprises and Corporate Social Responsibility: A systematic review of the literature. Qual. Quant. 2013, 47, 3205-3218.

74. Brutus, S.; Duniewicz, K. The many heels of Achilles: An analysis of self-reported limitations in leadership research. Leadersh. $Q$. 2012, 23, 202-212. [CrossRef]

75. Brutus, S.; Aguinis, H.; Wassmer, U. Self-Reported Limitations and Future Directions in Scholarly Reports: Analysis and Recommendations. J. Manag. 2013, 39, 48-75. [CrossRef]

76. Sawani, Y.; Zain, M.M.; Darus, F. Preliminary insights on sustainability reporting and assurance practices in Malaysia. Soc. Responsib. J. 2010, 6, 627-645. [CrossRef]

77. Dienes, D.; Sassen, R.; Fischer, J. What are the drivers of sustainability reporting? A systematic review. Sustain. Account., Manag. Policy J. 2016, 7, 154-189. [CrossRef]

78. Egri, C.P.; Ralston, D.A. Corporate responsibility: A review of international management research from 1998 to 2007. J. Int. Manag. 2008, 14, 319-339. [CrossRef]

79. Adhikariparajuli, M.; Hassan, A.; Fletcher, M.; Elamer, A.A. Integrated reporting in higher education: Insights from Scotland, Northern Ireland and Wales. Soc. Responsib. J. 2020. [CrossRef]

80. Rodrigues, M.; Mendes, L. Mapping the litreature on social responsibility in the mining industry: A systematic literature review. J. Clean. Prod. 2018, 181, 88-108. [CrossRef]

81. Jacob, S.A.; Furgerson, S.P. Writing Interview Protocols and Conducting Interviews: Tips for students New to the Field of Qualitative Research. Qual. Rep. 2012,17, 1-10.

82. Stoian, C.D. How to Deal with Corporate Social Responsibility in Financial Crisis. Ann. Univ. Apulensis Ser. Oeconomica 2013, 15, 333-338. [CrossRef]

83. Del Sordo, C.; Farneti, F.; Guthrie, J.; Pazzi, S.; Siboni, B. Social reports in Italian universities: Disclosures and preparers' perspective. Meditari Account. Res. 2016, 24, 91-110. [CrossRef]

84. Siboni, B.; Del Sordo, C.; Pazzi, S. Sustainability reporting in state universities: An investigation of Italian pioneering practices. Int. J. Soc. Ecol. Sustain. Dev. 2013, 4, 1-15. [CrossRef] 